\title{
ADBInstitute
}

ADBI Working Paper Series

THE EFFECTIVENESS OF JAPAN'S

NEGATIVE INTEREST RATE POLICY

Naoyuki Yoshino,

FarhadTaghizadeh-Hesary,

and Hiroaki Miyamoto

No. 652

January 2017

\section{Asian Development Bank Institute}


Naoyuki Yoshino is the dean of the Asian Development Bank Institute. Farhad Taghizadeh-Hesary is an assistant professor of economics at Keio University and a visiting professor at the Graduate School of Economics, University of Tokyo. Hiroaki Miyamoto is a project associate professor at the Graduate School of Public Policy, University of Tokyo.

The views expressed in this paper are the views of the author and do not necessarily reflect the views or policies of $A D B I, A D B$, its Board of Directors, or the governments they represent. ADBI does not guarantee the accuracy of the data included in this paper and accepts no responsibility for any consequences of their use. Terminology used may not necessarily be consistent with ADB official terms.

Working papers are subject to formal revision and correction before they are finalized and considered published.

The Working Paper series is a continuation of the formerly named Discussion Paper series; the numbering of the papers continued without interruption or change. ADBI's working papers reflect initial ideas on a topic and are posted online for discussion. ADBI encourages readers to post their comments on the main page for each working paper (given in the citation below). Some working papers may develop into other forms of publication.

\section{Suggested citation:}

Yoshino, N., F. Taghizadeh-Hesary, and H. Miyamoto. 2017.The Effectiveness of Japan's Negative Interest Rate Policy.ADBI Working Paper 652. Tokyo: Asian Development Bank Institute. Available: https://www.adb.org/publications/effectiveness-japan -negative-interestrate-policy

Please contact the authors for information about this paper.

Email: nyoshino@adbi.org

farhadth@keio.jp

miyamoto@pp.u-tokyo.ac.jp

Asian Development Bank Institute

Kasumigaseki Building, 8th Floor

3-2-5 Kasumigaseki, Chiyoda-ku

Tokyo 100-6008, Japan

Tel: $\quad+81-3-3593-5500$

Fax: $\quad+81-3-3593-5571$

URL: $\quad$ www.adbi.org

E-mail: info@adbi.org

(C) 2017Asian Development Bank Institute 


\begin{abstract}
In April 2013, the Bank of Japan (BOJ) introduced an inflation target of $2 \%$ with the aim of overcoming deflation and achieving sustainable economic growth. But due to lower international oil prices, it was unable to achieve this target and was forced to take further measures. Hence, in February 2016, the BOJ adopted a negative interest rate policy by massively increasing the money supply through purchasing long-term Japanese government bonds (JGB). The BOJ had previously purchased short-term government bonds mainly, a policy that flattened the yield curve of JGBs. On the one hand, banks reduced the numbers of government bonds because short-term bond yields had become negative, and even the interest rates of long-term government bonds up to 15 years became negative. On the other hand, bank loans to the corporate sector did not increase due to the Japanese economy's vertical investment-saving (IS) curve. This paper firstly explains why, in the view of the authors, the BOJ has to reduce its $2 \%$ inflation target in the present low oil price era. Secondly, it argues that Japan cannot make a sustainable recovery from its long-lasting recession and tackle its long-standing deflation problem by means of its current monetary policy and its negative interest rate policy in particular. It is of key importance to make the IS curve downward sloping rather than vertical. That means the rate of return on investment must be positive and companies must be willing to invest if interest rates are set too low. Japan's long-term recession is due to structural problems that cannot be solved by its current monetary policy. The last section reports our simulation results of tackling Japan's aging population by introducing a productivity-based wage rate and postponement of the retirement age, which will help the recovery of the Japanese economy.
\end{abstract}

JEL Classification:E43, E52, E12 


\section{Contents}

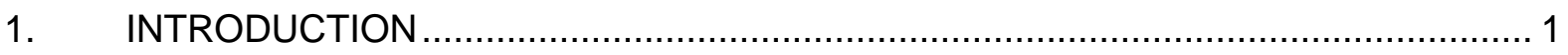

2. RECENT GLOBAL OIL PRICE MOVEMENTS …......................................... 1

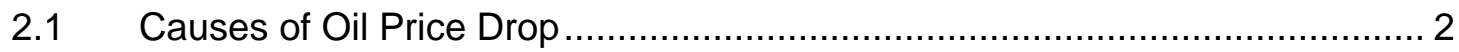

3. OIL PRICES AND THE JAPANESE ECONOMY ........................................... 3

4. LOWER OIL PRICES AND THE NEGATIVE INTEREST RATE POLICY

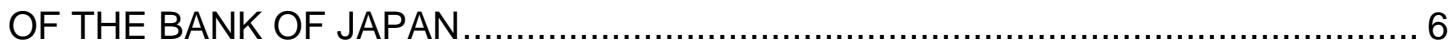

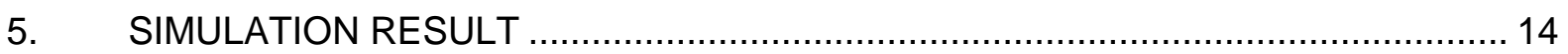

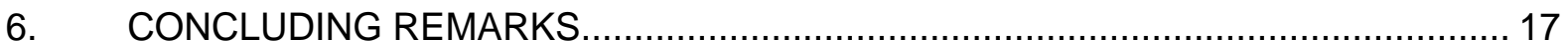

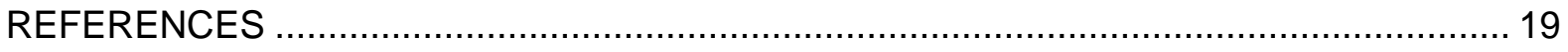




\section{INTRODUCTION}

On 22 January 2013, the Government of Japan and the Bank of Japan (BOJ) delivered a joint statement on overcoming deflation and achieving sustainable economic growth. The BOJ set the price stability target at 2\% (year-on-year rate of change in the consumer price index). Since then, the BOJ has been implementing aggressive monetary easing through buying long-term government bonds and increasing the monetary base, in contrast to previous expansionary monetary policy attempts, which mainly focused on buying short-term government bonds to achieve this target.

Although for some short periods in 2014 inflation reached the $2 \%$ target, this was mainly caused by higher energy prices, especially of oil, and because the consumption tax rate was raised from $5 \%$ to $8 \%$. Following the start of the oil price decline in the global market in June 2014, general price levels in Japan also started to decline. Oil prices dropped from over $\$ 100$ per barrel in June 2014 to less than $\$ 30$ per barrel in February 2016. Oil and other petroleum products make up a significant portion of total Japanese imports. That is why the price fluctuation of oil has a significant impact on Japanese macroeconomic variables, including on the inflation rate.

Although the price of oil is now less than half the price in early 2014, the BOJ has maintained its $2 \%$ inflation target. When the price of oil decreases, production becomes cheaper and the aggregate supply curve shifts to the right, decreasing the equilibrium price level. That means the target inflation rate needs to be reviewed and be lower.

The BOJ could not achieve a stable $2 \%$ inflation rate and hence further eased the interest rate. At its monetary policy meeting on 29 January 2016, the BOJ policy board decided to introduce "quantitative and qualitative monetary easing (QQE) with a negative interest rate" to achieve the price stability target of $2 \%$ at the earliest possible time. The BOJ started this policy by increasing the money supply through purchasing long-term Japanese government bonds (JGB). This policy has flattened the yield curve of JGBs and banks started to reduce purchasing government bonds because government bonds yields up to 15 years became negative.

In this paper we first shed light on the role of oil prices in the Japanese economy and in the price determination in Japan. We show why, in the current low oil price era, the BOJ needs to deflate the inflation targets. We also investigate whether the recent negative interest rate policy of the BOJ was effective, and provide some suggestions for overcoming deflation and achieving sustainable economic growth.

\section{RECENT GLOBAL OIL PRICE MOVEMENTS}

Oil prices dropped from over $\$ 100$ per barrel in June 2014 to less than $\$ 30$ per barrel in February 2016 (Figure 1). They started rising again in early April 2016 because of a fragile improvement in demand, but they are still less than half of the 2014 level. The sharp drop was due to several reasons related to supply and demand conditions and expectations in the oil market (for more information, refer to Yoshino and TaghizadehHesary 2016a). 
Figure 1: Recent Global Spot Oil Price Movements (4 Jan 2010-18 July 2016)

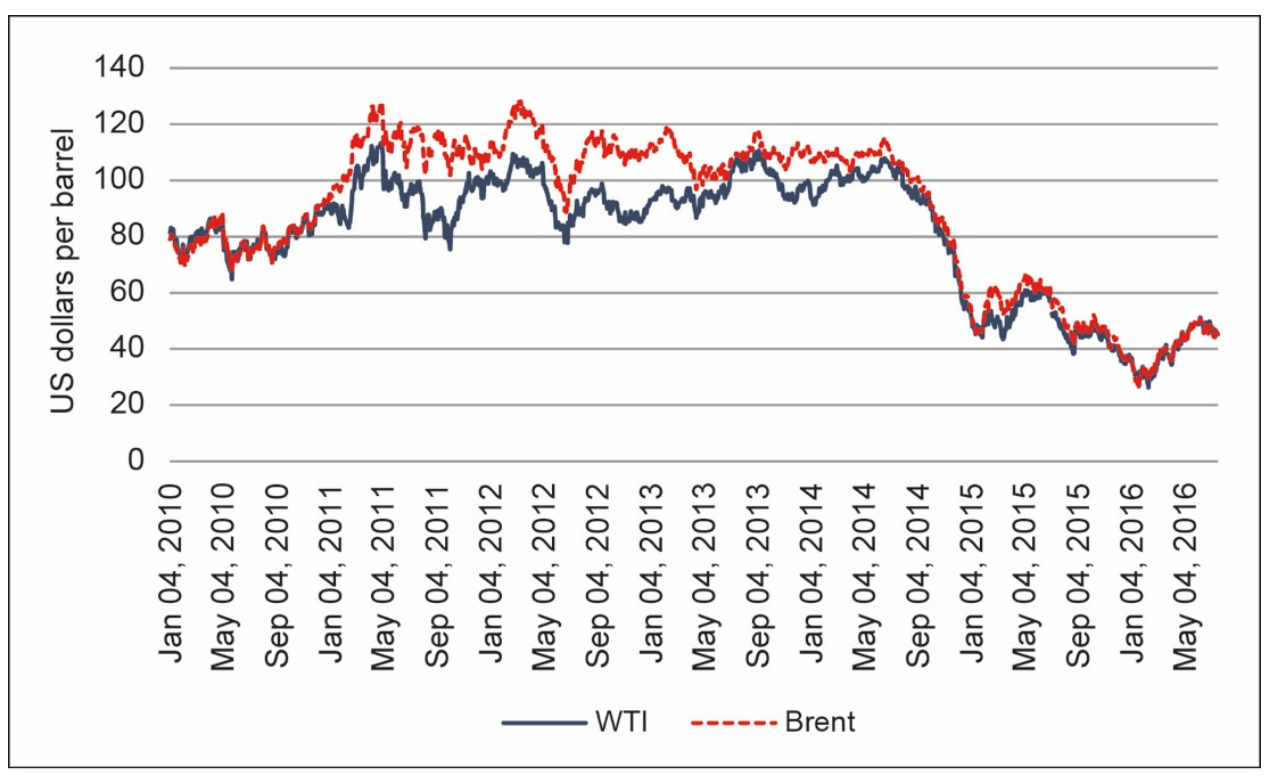

Note: WTI price is Cushing, OK West Texas Intermediate (WTI) Spot Price Free on Board (FOB) (US dollars per barrel); Brent price is Europe Brent Spot Price FOB (US dollars per barrel).

Source: US Energy Information Administration. http://www.eia.gov/dnav/pet/pet_pri_spt_s1_d.htm (accessed 20 December 2016).

\subsection{Causes of Oil Price Drop}

The price of oil is determined partly by actual supply and demand, and partly by expectations. Some of the recent price collapse can be attributed to a new glut in oil supply. Unconventional energy resources, such as shale oil, shale gas, and oil sands, have increased the global oil supply. Massive discoveries of oil in North Dakota and Texas in the United States (US) have driven down prices, and even amid tensions in the Middle East, roughly 3 million barrels more a day are being produced now than in 2011.

Moreover, while oil prices were falling, the Organization of the Petroleum Exporting Countries (OPEC), which controls nearly $40 \%$ of the world market, failed to reach an agreement on production curbs at its recent meetings, thus sending the price down even further.

Supply exceeded demand by massive margins of 0.9 million barrels per day $(\mathrm{mb} / \mathrm{d})$ in 2014 and 2.0mb/d in 2015. We expect a further increase in supply of $1.1 \mathrm{mb} / \mathrm{d}$ in 2016 (International Energy Agency 2016).

In 2014, global economic activity was subdued. The International Monetary Fund (IMF) reported global gross domestic product (GDP) growth of $3.4 \%$ in constant prices. Growth in emerging markets and developing economies-while still accounting for over $70 \%$ of global growth-declined for the fourth consecutive year, mostly driven by Brazil, the People's Republic of China, and Russian Federation. In 2015, global economic activity declined further, with GDP growth falling to 3.1\%. The IMF downgraded its global growth outlook for 2016 by $0.2 \%$ to 3.2\%, which is broadly in line with 2015 . Although the IMFforecasts a strengthening of the recovery in 2017, the situation in 2016 is expected to be the same as in 2015. The IMF also noted that uncertainty has increased, and that the risks of weaker growth scenarios are becoming more tangible. 
Before discussing how monetary policy was behind the drop in oil prices, let us look further back to the subprime mortgage crisis of 2008-2009 and review what happened to the US money market and global oil prices at that time.

After the subprime mortgage crisis, the weak exchange rate of the US dollar that had resulted from the Federal Reserve's quantitative easing policy pushed oil prices in US dollars upward during2009-2012 by causing investors to invest in the oil market and other commodity markets while the world economy was in recession. As a result, huge amounts of capital entered the crude oil market as investors found it safer than capital markets, which had collapsed (Yoshino and Taghizadeh-Hesary 2014a). Because of this new demand, oil prices started to rise sharply in 2009, when the US and many other economies were in recession. This trend had the effect of imposing a longer recovery time on the global economy, as oil is one of the most important production inputs.

In 2014, financial conditions eased compared with2013. In particular, long-term interest rates declined in developed economies because of the economic recovery and expectations of a lower neutral policy rate in the US over the medium term.

Equity prices have generally risen and risk premiums declined in developed economies and emerging markets. In the US, both the Dow Jones Industrial Average and Standard and Poor's 500 Index powered to record highs, boosted by the strengthening US economy and liquidity provided by the Federal Reserve's unprecedented quantitative easing. The Dow, up 8.5\%, surpassed two key psychological levels during 2014-17,000 and 18,000-and the Standard \&Poor's 500, 12.8\% higher, surpassed the 2,000 milestone.

The liquidity provided mainly by the Federal Reserve, especially during the 2008-2009 financial crisis, transferred to the oil market and created huge speculative demand causing a surge in oil prices. In 2014, because the US and some other developed and emerging capital markets were recovering, liquiditymoved back to the capital markets, resulting in a depressed global oil demand growth rate and a price collapse in the market. This means that this factor may have played a bigger role in reducing oil prices than supply and lower economic growth(Yoshino and Taghizadeh-Hesary 2016a).

\section{OIL PRICES AND THE JAPANESE ECONOMY}

In 2015, the total value of Japan's imports was $\$ 648$ billion, $\$ 150$ billion (23\%) of which was mineral fuels, $\$ 67$ billion petroleum, $\$ 46$ billion liquid natural gas, $\$ 16$ billion coal, $\$ 15$ billion petroleum products, and $\$ 5$ billion liquefied petroleum gas (Figure 2). Although Japan's crude oil imports in 2015 fell to their lowest level since 1988 as demand had been weakening due in part to a declining population, slower economic growth, and more energy- efficient vehicles and industries, oil is still the main mover of the Japanese economy and Japan remains the third largest consumer of crude oil behind the US and the People's Republic of China. 
Figure 2: Japan's Imports by Principal Commodity, 2015 (thousands of \$)

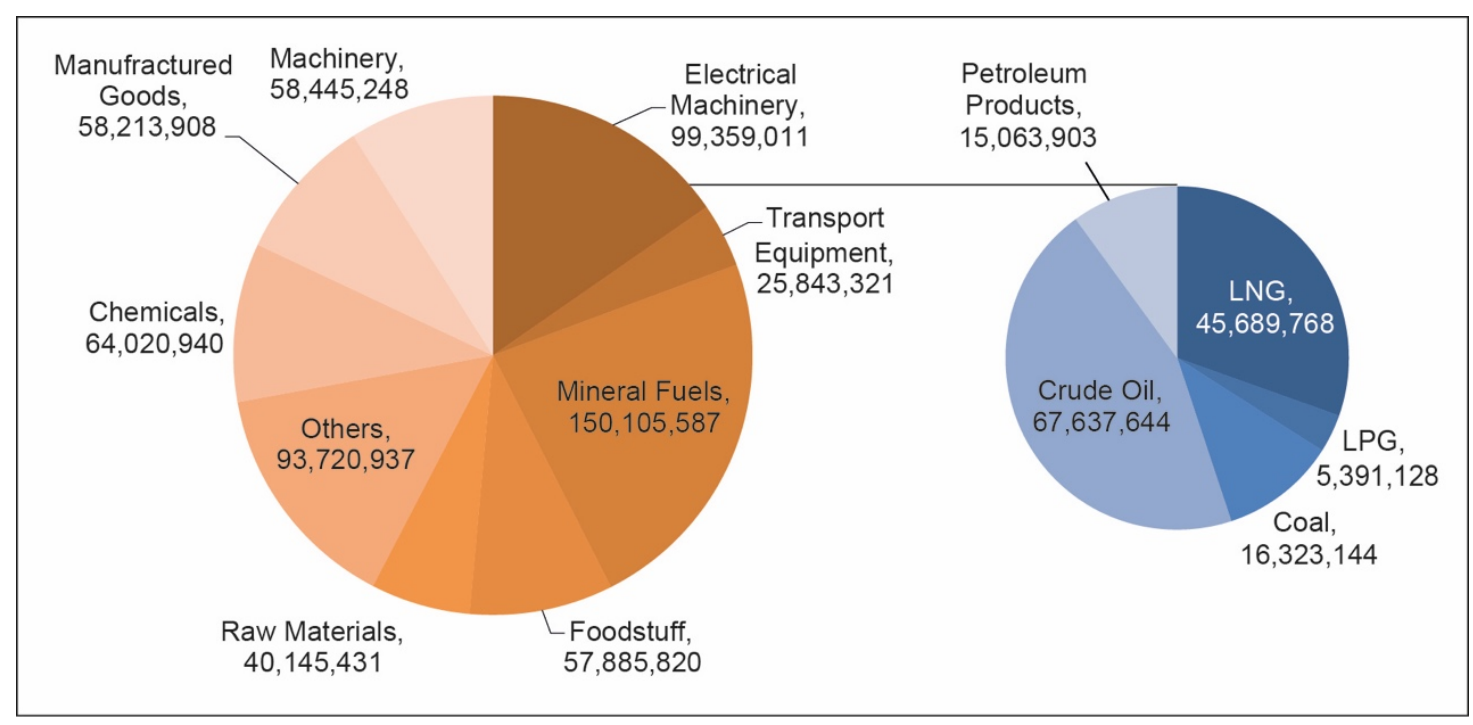

LNG = liquefied natural gas, LPG = liquefied petroleum gas.

Source: Japan External Trade Organization(2016).

Japan is dependent on imports for $91.4 \%$ of its energy supply. Since the Fukushima nuclear disaster in 2011, the share of fossil fuels in power generation has been increasing, as a substitute for nuclear power. The level of dependence on petroleum, which had been declining in recent years, increased to 47.2\% in fiscal year (FY) 2012. In FY2013, the total primary energy supply in Japan was 21,973 petajoules, up 1.1\% from the previous $\mathrm{FY}$, broken down as follows: $45.7 \%$ was petroleum, $24.2 \%$ coal, $22.5 \%$ natural gas, $3.1 \%$ hydropower, and $0.4 \%$ nuclear power. Other sources were also used, though only in small quantities, including energy from waste, geothermal energy, and natural energy (solar photovoltaic power, wind power, biomass energy, among others) (MIAC 2015).

The result of eliminating nuclear power generation and substituting it with fossil fuels was that the energy self-sufficiency ${ }^{1}$ percentage fell from $19.6 \%$ in FY2000 to $8.6 \%$ in FY2013 (MIAC 2015). Before the 2011 Great East Japan Earthquake, Japan was the third largest consumer of nuclear power in the world, after the US and France, with nuclear power accounting for about 13\% of the country's total energy consumption in 2010 (Taghizadeh-Hesary et al. 2015a). In 2012, the share of nuclear energy fell to 1\% of total energy consumption, contributing a similar level to primary energy consumption in 2013 as only two reactors were operating for a little more than half the year, and in 2014 Japan did not produce any nuclear power (Taghizadeh-Hesary and Yoshino 2015).

The great importance of oil for the Japanese economy means oil price movements have significant effects on Japanese macroeconomic variables including economic growth and the inflation rate. Several scholars have shown this (Hamilton 1996; Lee, Lee, and Ratti 2001; Blanchard and Gali 2007; Kilian 2008; Taghizadeh-Hesary et al. 2013, 2015a; Yoshino and Taghizadeh-Hesary 2015a).

Yoshino and Taghizadeh-Hesary (2015a), by developing a simultaneous equation model consisting of the Phillips curve (aggregate supply), aggregate demand, and the Taylor rule equations, tried to find out whether the achieved inflation rate in

1 Domestic production of primary energy (including nuclear)/domestic supply of primary energy $\times 100$. 
Japan,following the quantitative and qualitative monetary easingof the BOJ since 2013, was caused by monetary policy or by higher oil prices. The results are presented in Table 1.

Table 1: Oil Prices and Inflation Rate in Japan

\begin{tabular}{lcc}
\hline & Q2 1994-Q4 2001 & Q1 2002-Q2 2014 \\
\hline Phillips curve (Inflation rate) & & $-0.36(-1.12)$ \\
Lagged inflation rate & $0.89(4.08)^{\star \star}$ & $-0.24(-0.45)$ \\
GDP gap & $0.69(2.18)^{\star}$ & $0.07(2.59)^{\star \star}$ \\
Crude oil price & $0.06(3.27)^{\star \star}$ & $0.05(1.17)$ \\
Gas price & $0.03(0.45)$ & \\
\hline Aggregate demand (GDP gap) & & $-0.02(-1.09)$ \\
Long-term real interest rate & $-0.02(-4.71)^{\star \star}$ & $0.42(1.52)$ \\
Lagged GDP gap & $-0.33(-1.66)$ & $0.07(1.17)$ \\
Exchange rate & $0.09(2.18)^{\star}$ & $1.94(2.16)^{\star}$ \\
\hline Taylor rule (short-term interest rate) & $1.21(0.67)$ & $3.89(3.01)^{\star *}$ \\
Inflation rate & $4.76(2.72)^{\star \star}$ & \\
GDP gap & & \\
GDP $=$ gross domestic product. & & \\
Notes: T-statistics are in parentheses. * indicates significance at $5 \% .{ }^{* *}$ indicates significance at $1 \%$. \\
Source: Yoshino and Taghizadeh-Hesary (2015a).
\end{tabular}

The first part of Table 1 is the Phillips curve equation, which is the aggregate supply function. The y-axis of the Phillips curve is the inflation rate, and the $x$-axis is the GDP gap. Usually, the aggregate supply curve is upward sloping, which means the GDP gap and the inflation rateshould be positively related. The results for Q2 1994-Q4 2001 are in accordance with an upward sloping aggregate supply, which means a larger GDP gap tended to result in a higher inflation rate in the first period. When the economy is in an inflationary environment, that will accelerate current inflation even more, so in this situation lagged inflation should have a positive impact on the current inflation rate, which is what happened in the first period of this analysis. However, after 2002, Japan was faced with deflation and a decreasing GDP gap, so the results show that the lagged inflation rate and the GDP gap in the Phillips curve are not significant in the second period of this analysis, which is indeed the case. This means (i) the current year's inflation was not affected by lagged inflation rates, and (ii) because the economy was in recession, the GDP gap was negative and had no impact on the inflation rate. However, the rising crude oil price shifted up the aggregate supply curve because imports of oil created inflationary pressure. Therefore, the positive sign of the crude oil price in both periods is correct. This finding is in accordance with the paper's hypothesis. Although inflation was created after the adoption of QQE, we believe this was due mainly to other factors, especially higher oil prices. Following the easy monetary policy of the BOJ, the yen started to depreciate heavily, which increased prices of crude oil and other energy imports, pushing up production costs and creating inflation. Yoshino and Taghizadeh-Hesary's (2015a) results support this assertion. In the second period, the sign of the output gap in the Phillips curve equation was not significant, which means that the economy was in recession and aggregate demand did not rise enough to have an impact on price levels. However, the higher oil price in yen, which was mainly the result of easy monetary policy, has had a significant impact on general price levels and has been a negative development for Japanese manufacturers. 
The second part of Table 1 is aggregate demand. It is clear that in the second period long-term interest rates did not have any significant association with the GDP gap. This means the QQE policies that cut the short-term and long-term interest rates could neither stimulate the economy nor create inflation. And as mentioned above, the general price inflation in that period was due to other factors, mainly the oil price.

The third part of Table 1 is the Taylor rule, which depends on inflation and the GDP gap. If the inflation rate keeps on going up, the central bank will tighten monetary policy, so the inflation rate should have a positive sign (Yoshino, Taghizadeh-Hesary, Hassanzadeh, and Prasetyo 2014). It is positive in both periods, but significant only in the second period. With regard to the GDP gap, it widened during Q2 1994-Q4 2001. When current GDP is higher than full employment GDP, the economy is accelerating, at which point the central bank usually tries to tighten the money market, so the GDP gap should have a positive sign in line with the Taylor rule. After 2002, Japan was faced with recession, so the GDP gap became negative; the central bank then lowered the short-term interest rate, and again the GDP gap should have a positive sign in line with the Taylor rule.

\section{LOWER OIL PRICES AND THE NEGATIVE INTEREST RATE POLICY OF THE BANK OF JAPAN}

In 2013 , the BOJ set a price stability target of $2 \%$ (year-on-year rate of change in the consumer price index). On 4 April 2013, the BOJ announced that, based on a decision at its monetary policy meeting, it would purchase Japanese government bonds, effective 5 April 2013. This decision was madeat the first monetary policy meeting after Haruhiko Kuroda had taken up his post as the new governor of the BOJ.

Figure 3: Expansion in the Monetary Base and Japanese Government Bond Holdings

(January 2000-June 2016)

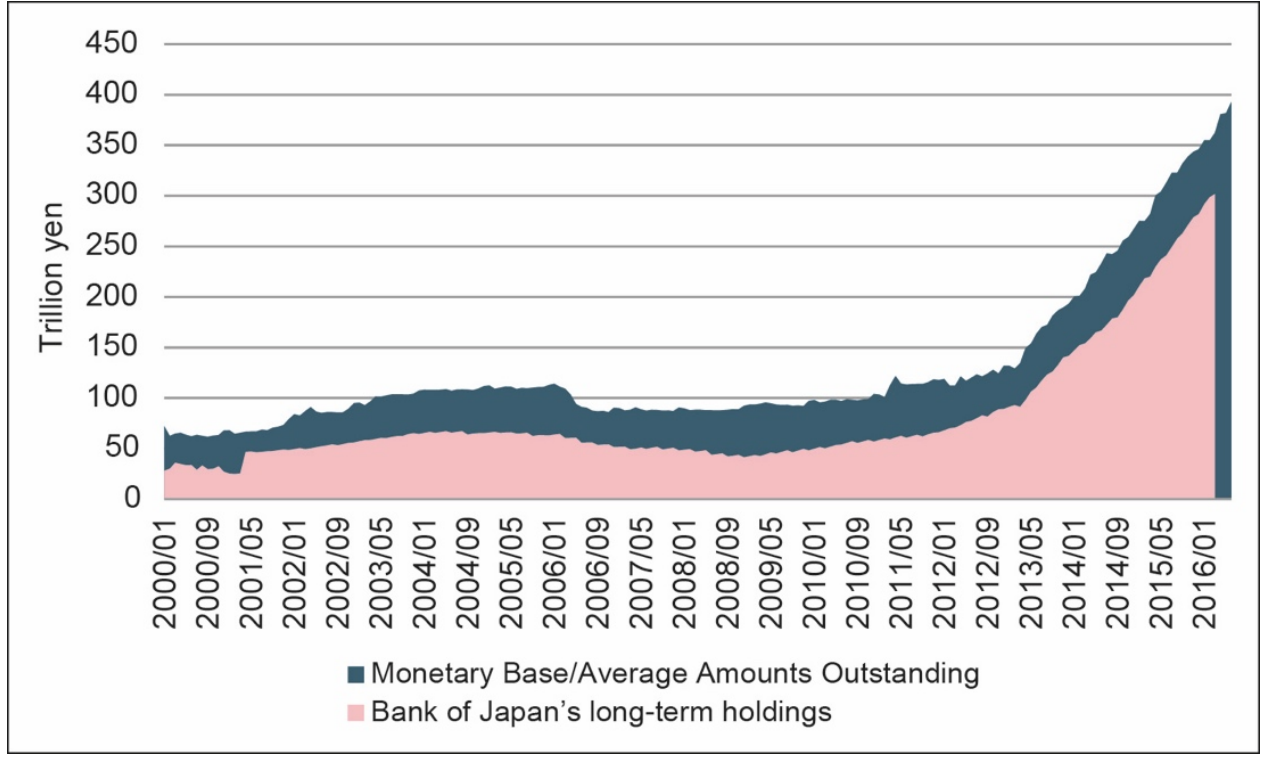

JGB = Japanese government bond.

Notes: Monetary base is average amounts outstanding in each month. Bank of Japan's long-term JGB holding data was available up to March 2016.

Source: Bank of Japan.Time-series database.https://www.stat-search.boj.or.jp/index_en.html (accessed 30 July 2016). 
Figure 3 shows the expansion of the monetary base and JGB holdings by the BOJ. Since 2013, there has been a massive increase in the amount of monetary base through the implementation of the QQE policy after Prime Minister Shinzō Abe came to power for the second time. On the liability side of the BOJ's balance sheet, the monetary base increased drastically. Table 2 shows the asset side of the BOJ's balance sheet. In April 2013, assets amounted to $¥ 175$ trillion and by May 2016 they had expanded to $¥ 426$ trillion, an increase of almost 2.5 times in 3 years. In the same period, JGBs, which were the major purchase of the BOJ, went up from $¥ 98$ trillion to $¥ 319$ trillion. In other words, the major part of the asset is the purchase of long-term government bonds. Figure 3 shows that there was a parallel increase in the monetary base and the JGB holdings by the BOJ after 2013.

Table 2: Monetary Base and Japanese Government BondPurchase Data (comparison of April 2013 with May 2016)

(¥ trillion)

\begin{tabular}{lccl}
\hline & $\begin{array}{c}\text { April 2013 } \\
\text { (actual) }\end{array}$ & $\begin{array}{c}\text { May 2016 } \\
\text { (actual) }\end{array}$ & \multicolumn{1}{c}{ Average Annual Increase } \\
\hline Monetary Base & 155 & 387 & About 80 trillion \\
JGB & 98 & 319 & About 80 trillion \\
CP & 1.4 & 2.3 & Outstanding balance maintained \\
Corporate Bonds & 2.9 & 3.2 & Outstanding balance maintained \\
ETFs & 1.7 & 8.0 & About 3 trillion \\
J-REITs & 0.13 & 0.31 & About 90 billion \\
Total Assets of the BOJ & 175 & 426 & - \\
\hline
\end{tabular}

$\mathrm{BOJ}=$ Bank of Japan, $\mathrm{CP}=$ commercial paper,ETFs = exchange-traded funds, J-REITs = Japan real estate investment trusts, JGB = Japanese government bond.

Source: Bank of Japan. Time-series database. https://www.stat-search.boj.or.jp/index_en.html(accessed 30 July 2016).

In Table 3, the monetary base/GDP ratios of Japan are compared with those of the US and the eurozone. In July 2016, the ratio was $80 \%$ in Japan, $21 \%$ in the US, and $20 \%$ in the eurozone.

Table 3: Monetary Base/Gross Domestic ProductRatio for Japan, United States, and Eurozone

(\%)

\begin{tabular}{lccccc}
\hline & Dec 2000 & \multicolumn{2}{c}{ Dec 2012 } & \multicolumn{2}{c}{ Jul 2016 } \\
\cline { 2 - 6 } & $\begin{array}{c}\text { Monetary } \\
\text { Base/GDP }\end{array}$ & $\begin{array}{c}\text { Monthly QE } \\
\text { Volume/GDP }\end{array}$ & $\begin{array}{c}\text { Monetary } \\
\text { Base/GDP }\end{array}$ & $\begin{array}{c}\text { Monthly QE } \\
\text { Volume/GDP }\end{array}$ & $\begin{array}{c}\text { Monetary } \\
\text { Base/GDP }\end{array}$ \\
\hline Japan & 15 & 0.2 & 29 & 1.3 & 80 \\
US & 6 & 0.5 & 16 & - & 21 \\
Eurozone & 7 & - & 17 & 0.8 & 20 \\
\hline
\end{tabular}

$\mathrm{GDP}=$ gross domestic product, $\mathrm{QE}=$ quantitative easing, US = United States.

Source:International Monetary Fund, International Financial Statistics(2016)

As mentioned above, the BOJ has been maintaining its $2 \%$ inflation rate target. Butthe Japanese inflation rate exceeded $1.5 \%$ for short periods only, mostly during 2014 , and this was due mainly to an increase in consumption tax and higher oil prices.But after oil prices fell, the consumer price index also felland the inflation rate dropped to below $1 \%$ (Figure 4). 
Figure 4: Inflation Rate in Japan

(January 2005-March 2016, \%)

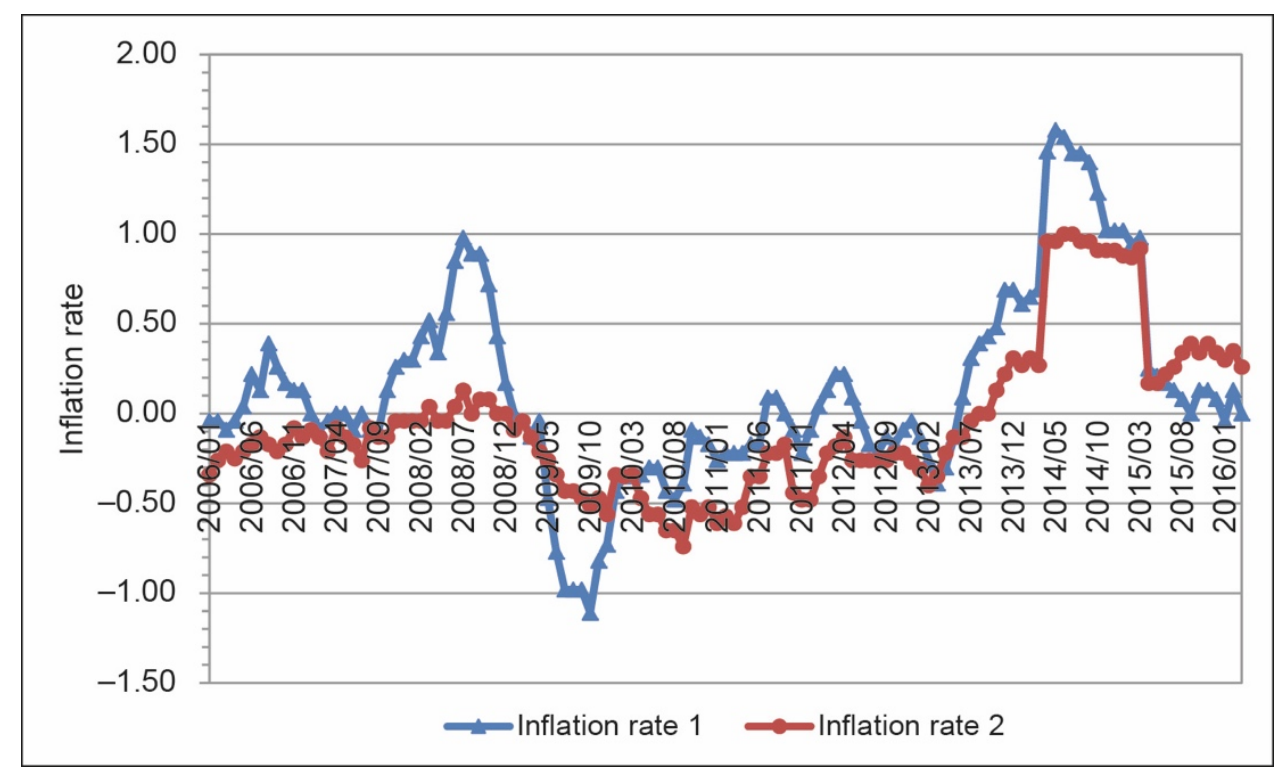

Note: Inflation 1: Consumer price index (CPI) general inflation rate of Japan (year-on-year changes). Inflation 2: $\mathrm{CPI}$ general inflation rate, excluding food and alcoholic beverages, and energy inflation rate of Japan (year-on-year changes).

Source: Nikkei Economic Electronic Databank System, http://www.nikkeieu.com/needs/(accessed 5 August 2016).

Due to falling oil prices, on the one hand, the aggregate supply (AS) curve shifts to the right and will reduce general price levels because oil, as the main energy provider, is one of the production inputs. Hence, declining oil prices lead to cheaper input prices for production, which is good news for suppliers and manufacturers of commodities. On the other hand, aggregate demand (AD) will also shift to the right because consumption of oil and derivatives will be cheaper and this will offset part of the earlier price decrease by the shifting of the AS curve. However, the shift in $A D$ in the Japanese case is less for several reasons, two of the most important being the aging population and more efficient automobiles that reduced the consumption and elasticity of oil and petroleum products with respect to prices. Taghizadeh-Hesary, Rasolinezhad, and Kobayashi (2015b) found that among Japanese oil consuming sectors, the commercial and industrial sectors show a significant response to oil price fluctuations, while the residential sector does not. They also found that in the wake of the Fukushima nuclear disaster in 2011, almost all economic sectors had a lower sensitivity to oil price fluctuations because Japan's dependency on oil increased.

With a simple AD-AS illustration, Figure 5 shows that following the decline in oil prices, the final equilibrium rate of inflation decreases. This means that the $2 \%$ inflation target may not necessarily be appropriate in the current cheap oil era. 
Figure 5: Lower Oil Prices, Lower Inflation Rate Target

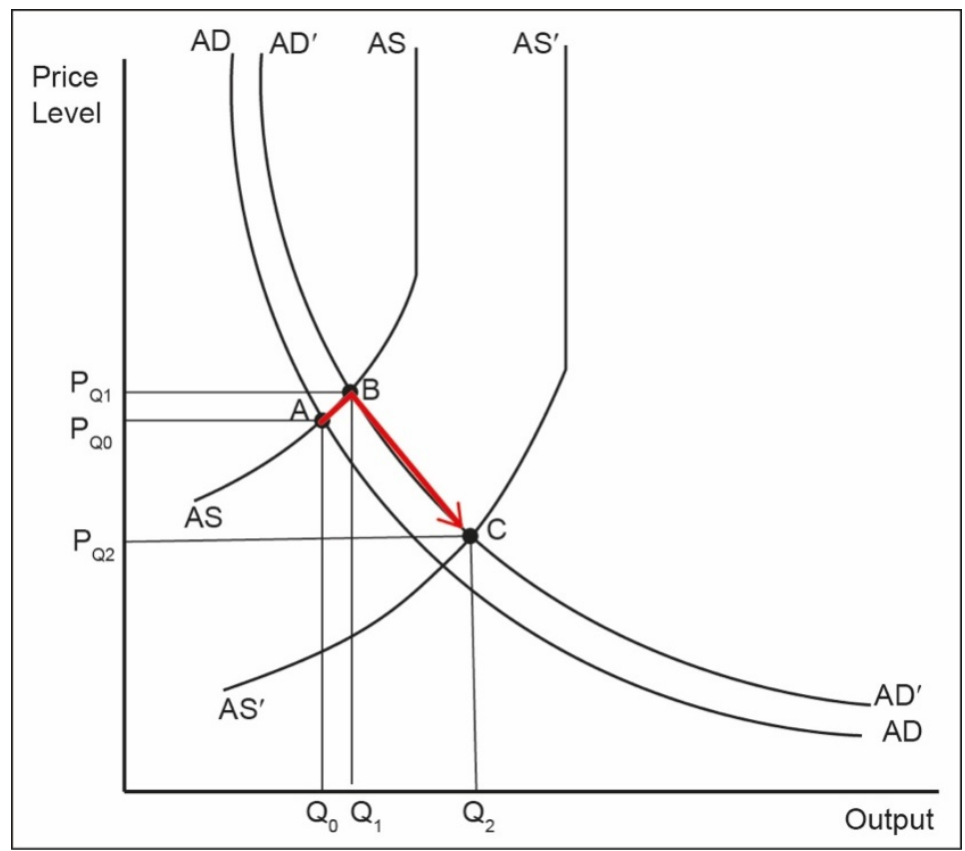

$A D=$ aggregate demand, $A S$ = aggregate supply.

Source: Taghizadeh-Hesary and Yoshino (2013).

At its monetary policy meeting on 29 January 2016, the BOJ policy board introduced QQE with a negative interest rate to achieve the price stability target of $2 \%$ at the earliest possible time. As shown in Figure 6, since February 2016, the short-term interest rate (call rate-overnight uncollateralized interest rate) has been negative.

Figure 6: Short-term Interest Rate in Japan (January 2012-May 2016, \%)

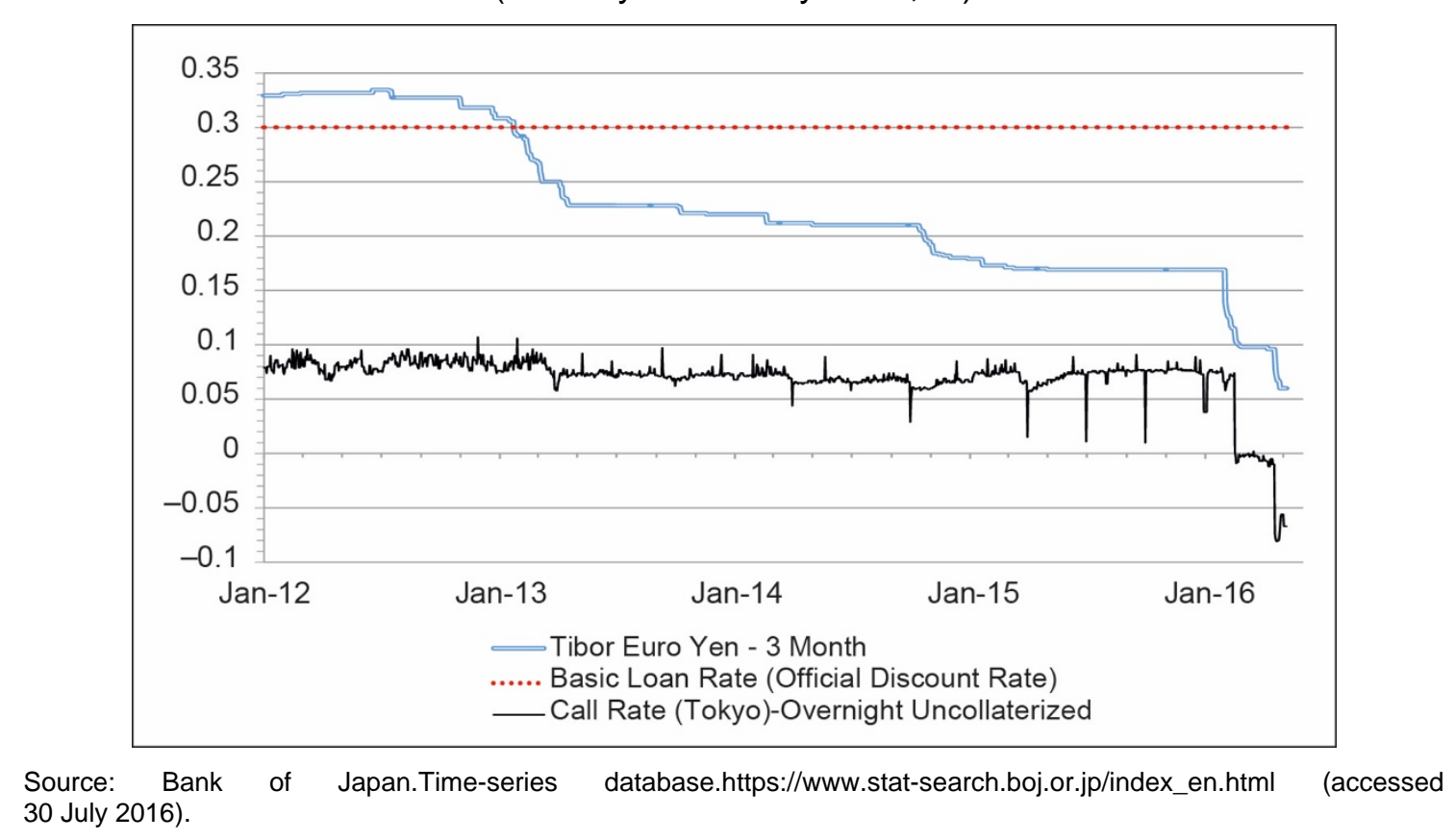


The BOJ decided to pursue monetary easing by making full use of possible measures in terms of three dimensions: (i) quantity, (ii) quality, and (iii) interest rate, and to do so issued the following guidelines (BOJ 2016):

(i) Quantity dimension. "The guideline for money market operations: The BOJ conducts money market operations so that the monetary base increases at an annual pace of about 80 trillion yen."

(ii) Quality dimension. "The guidelines for asset purchases: a) The Bank will purchase Japanese government bonds (JGBs) so that their amount outstanding will increase at an annual pace of about 80 trillion yen. With a view to encouraging a decline in interest rates across the entire yield curve, the Bank will conduct purchases in a flexible manner in accordance with financial market conditions. The average remaining maturity of the Bank's JGB purchases will be about 7-12 years. b) The Bank will purchase exchange-traded funds (ETFs) and Japan real estate investment trusts (J-REITs) so that their amounts outstanding will increase at annual paces of about 3 trillion yen and about 90 billion yen, respectively. c) As for $\mathrm{CP}$ and corporate bonds, the Bank will maintain their amounts outstanding at about 2.2 trillion yen and about 3.2 trillion yen, respectively."

(iii) Interest-Ratedimension. "The introduction of a negative interest rate: The Bank will apply a negative interest rate of minus $0.1 \%$ to current accounts that financial institutions hold at the Bank. It will cut the interest rate further into negative territory if judged as necessary." Specifically, the BOJ adopted a three-tier system in which the outstanding balance of each financial institution's current account at the $\mathrm{BOJ}$ is divided into three tiers. A positive interest rate, a zero interest rate, or a negative interest rate is applied to each of the tiers.

Although the BOJ published the abovementioned guidelines on 29 January 2016, the short-term negative interest rate also affected the long-term government bond interest rate and the JGB yield curve started to fall and flattened (Figure 7). The BOJ had not expected this to happen. This means it is not rational to hold government bonds until maturity, as the value of 100 at maturity will be less than 100 (i.e., 99, 98, 97, 96, or less). Hence, investors, especially overseas investors, are trading the bonds rather than keeping them until maturity. The nominal interest rate has dropped (Figure 9), but the volatility of the bond market has increased because of higher trading of bonds. As for holdings of government bonds, long-term bonds longer than 17 years have a positive yield, but nobody wants to keep bonds that are shorter than 17 years until maturity because the interest rate is negative.

Following its 29 January meeting, the BOJ started charging negative interest rate on excess reserves kept by commercial banks at the BOJ. Despite a massive increase of the money supply by the BOJ, bank loans have decreased, not increased (Figure 11). See Figure 8 for the recent behavior of Japanese banks. 
Figure 7: Japanese Government Bond Yield Curves

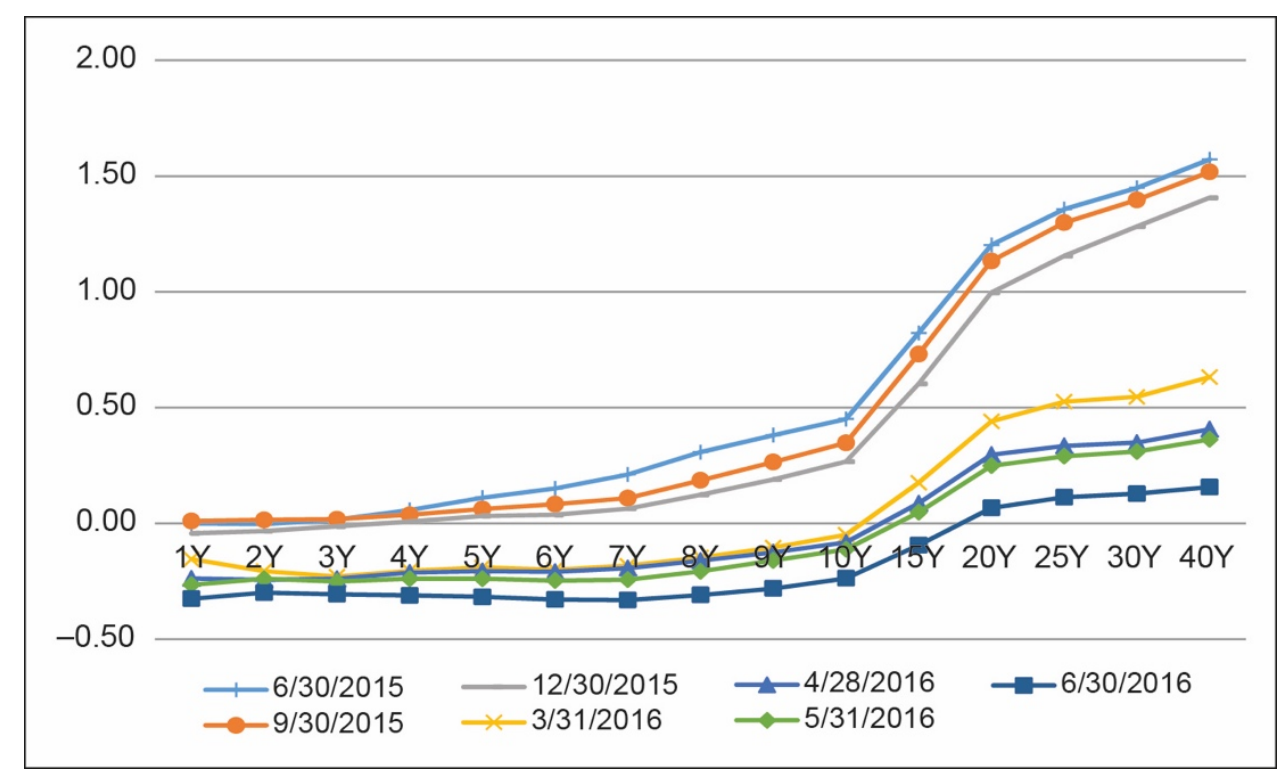

Source: Ministry of Finance of Japan, Financial Bureau(2016).

Figure 8: Bank of Japan's and Japanese Banks' More Recent Balance Sheets

\begin{tabular}{|l|lll|l|}
\hline \multicolumn{2}{|c|}{ Bank of Japan } & \multicolumn{2}{c|}{ Banking Behavior } \\
\hline $\begin{array}{l}\text { Foreign } \\
\text { Reserves }\end{array}$ & RR & & RR & Deposits \\
& ER(1) & & ER (1) & \\
Government & Money & & (2) Loans & \\
$\begin{array}{l}\text { Bonds } \\
\text { (JGB) }\end{array}$ & Supply & & & Capital \\
& & & & \\
\hline
\end{tabular}

$\mathrm{ER}=$ excess reserve, $\mathrm{RR}=$ reserve requirement.

Source: Authors' compilation.

More recently, there has been greater demand from overseas investors for short-term bonds (Treasury or T-bills). As shown in Figure 10 (B), 49\% of the holders of T-billsare foreigners who are buying and selling short-term Japanese government bonds and making a profit. This is the reason for the recent increase in volatility of the Japanese bond market.

The BOJ increased its purchases of government bonds from $¥ 98$ trillion in April 2013to $¥ 324$ trillion in June 2016. The BOJ started to purchase long-term government bonds. As shown in Figure 9, the shift in demand is mainly a result of the BOJ's policy, which increases the price, and at the same time decreases the interest rate, of long-term government bonds. That is why the JGB yield curve shifted downward (Figure 7).

The BOJ wants the yield curve to become positive in the long term and become steeper compared to the current yield curve. To do so, the BOJ will start to purchase short-term government bonds rather than long-term bonds. 
Figure 9: Inverse Relationship between Price of Bonds and Interest Rate

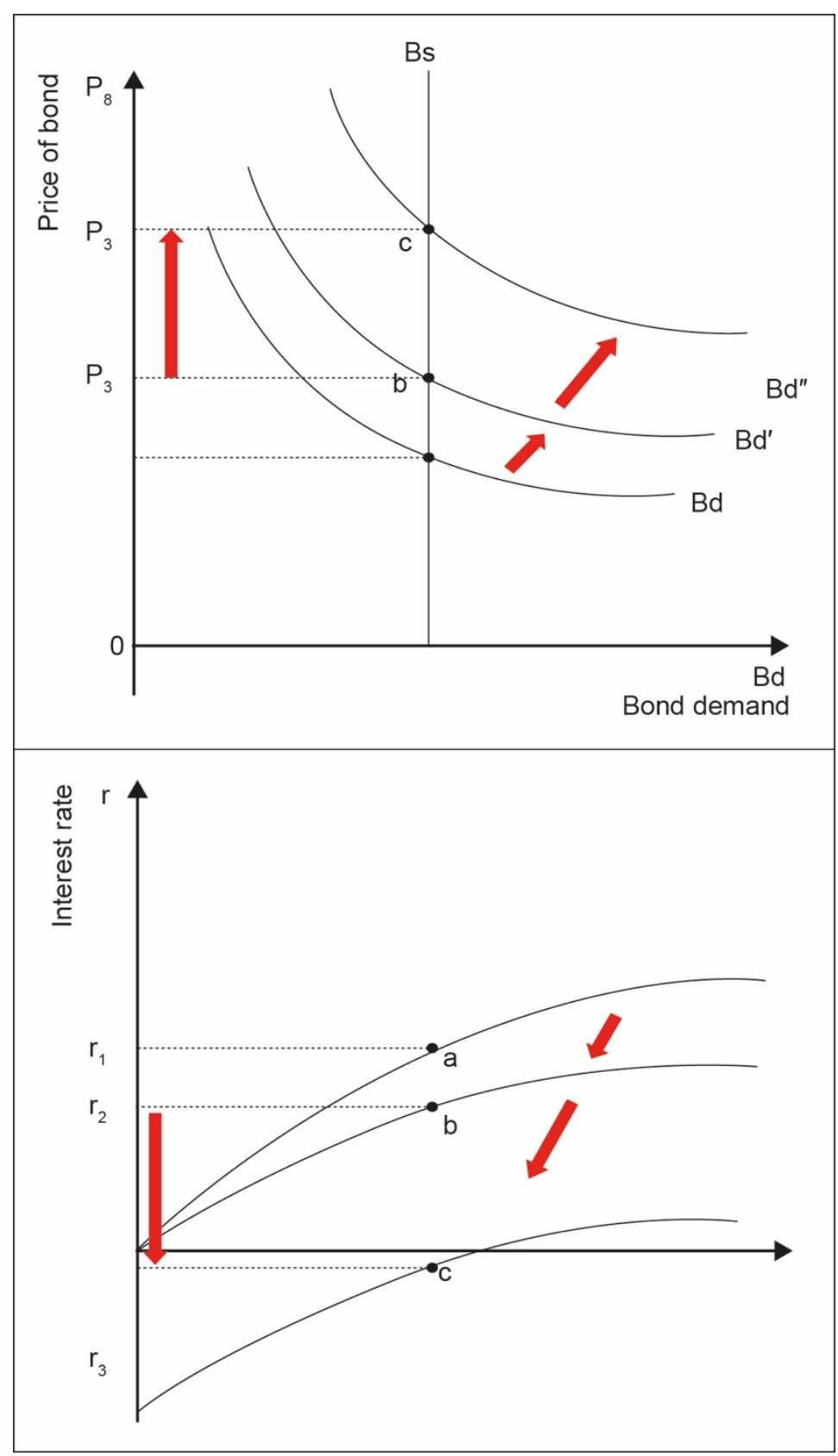

Source: Authors' compilation.

As can be seen in Figure $10 \mathrm{~A}$ ), the share of households holding JGBs is very small $(1 \%)$, as they are no longer interested in holding these bonds because of negative interest rates.

Among households, the Japanese saving rate is falling because of the aging population and lower economic growth rate, while the corporate sector saves more than households. Corporate savings are going to banks or insurance companies. In conventional cases, banks should lend money; however, because of the decreased demand for loans, bank lending is decreasing (Figure 11). Due to the Japanese economy's vertical investment-saving (IS) curve, the rate of return on investment and companies' willingness to invest have become very low. Hence, loans are diminishing 
and banks are holding government bonds instead. So on the asset side of Japanese banks, we can see predominantly JGBs.

Figure 10: Breakdown by Japanese Government Bond and T-bill holders (March 2016, \%)

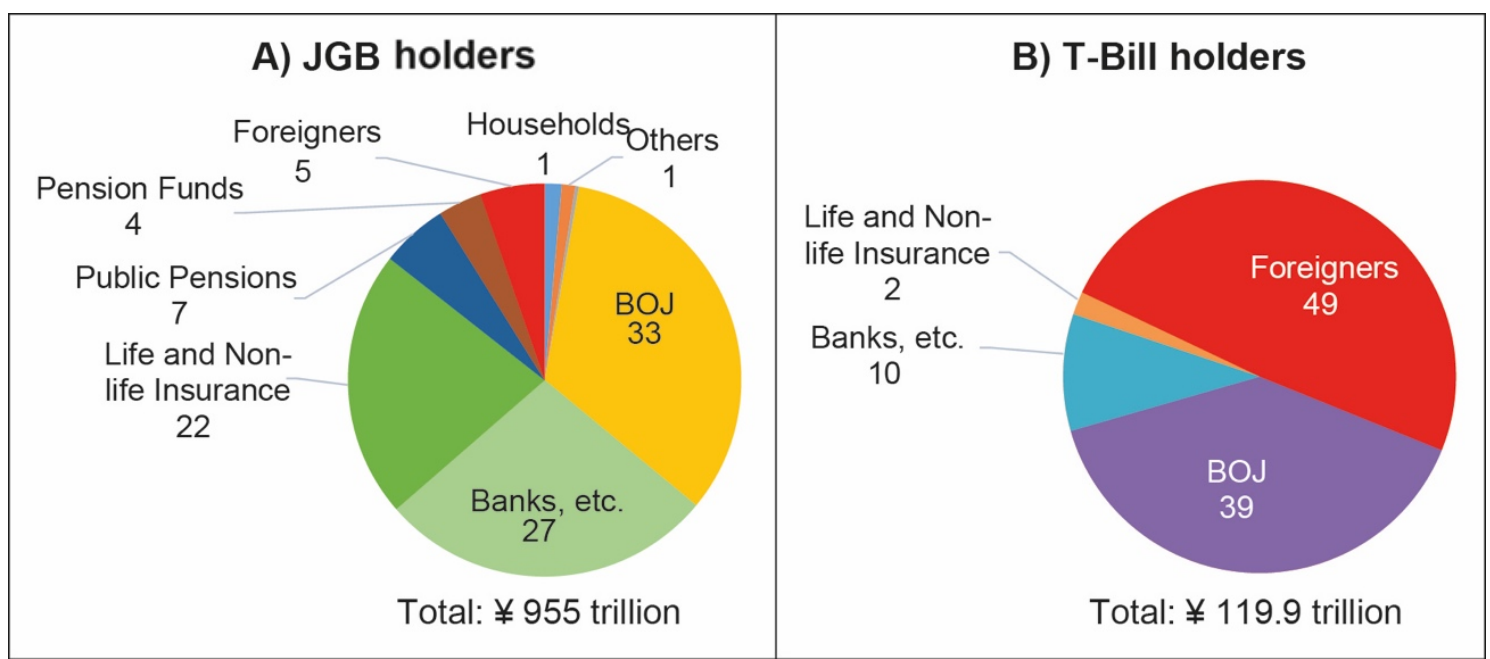

BOJ = Bank of Japan, JGB = Japanese government bond, T-bill = treasury bill.

Source: Ministry of Finance of Japan, Financial Bureau(2016).

Figure 11: Declining Bank Loans in Japan

(Q1 2005-Q4 2014)

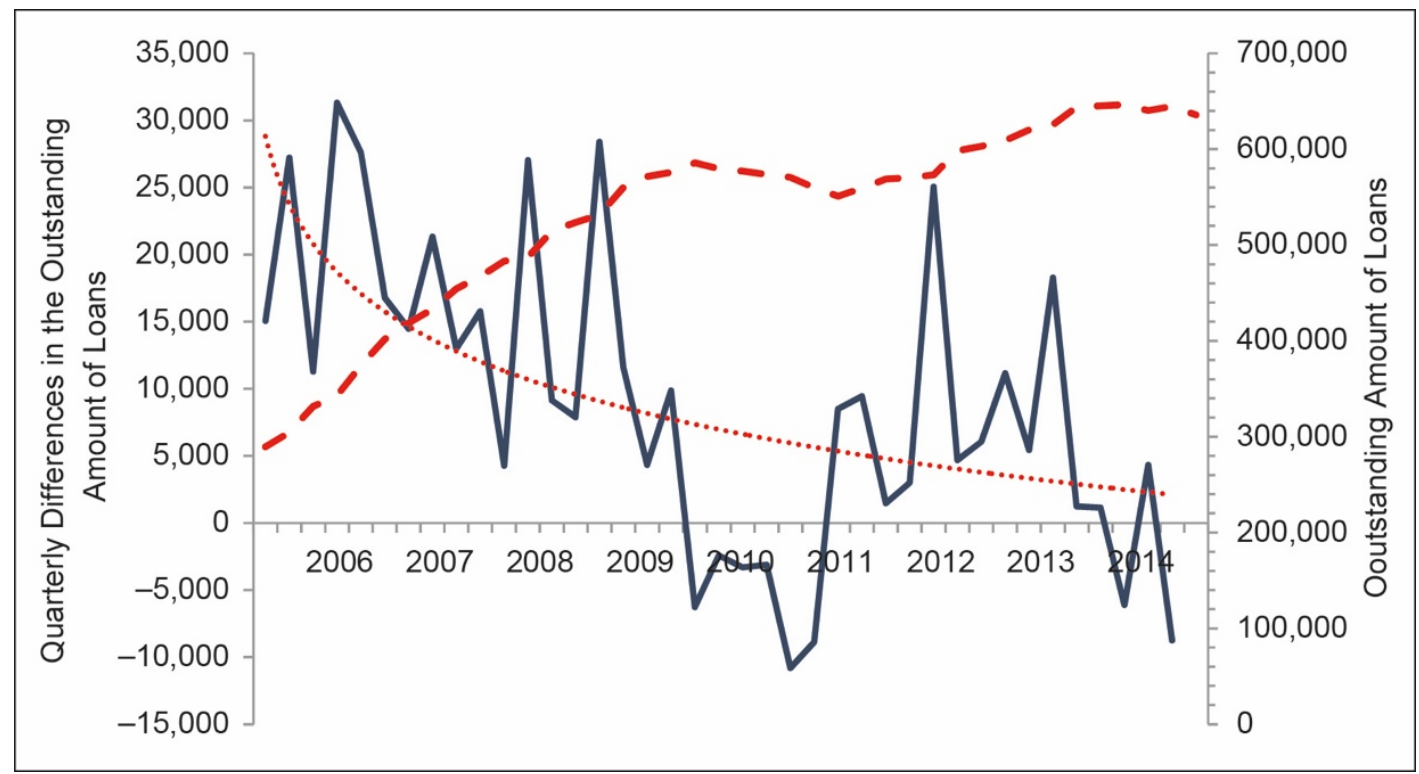

Note: The constant line shows the quarterly differences in the outstanding amount of loans (left-hand side axis); the dashed line shows the outstanding amount of loans (right-hand side axis); and the dotted line is the logarithmic trend of the quarterly differences in the outstanding amount of loans.

Source: Japanese Bankers Association database (2016).

During the current Japanese government, attention is focused more on monetary policy rather than structural issues, but the problem of the Japanese economy is its vertical IS curve (Figure 12). Private investment did not grow despite very low interest rates. Expected rates of return are low, and consequently not many new technologies are developed in Japan. Even though the central bank's short-term interest rate is now 
negative, depressed investment in Japan means that the economy is not able to recover (Yoshino and Taghizadeh-Hesary 2016b). This is in accordance with Table 1. The aggregate demand row, where during the second period real interest rate movements had no significant impact on the GDP gap, is a reflection of the vertical IS curve.

Corporate restructuring to reduce idle capacity and start new investments was not pursued, with too much criticism aimed at monetary policy instead of accelerating corporate restructuring (Yoshino and Taghizadeh-Hesary 2015b).

However, there has been a recent change in banking behavior. After 2012, demand for JGBs fell both in large city banks and regional banks. Instead, because of higher interest rates on deposits at BOJ, banks increased their excess reserves at the BOJ. But this new negative interest rate policy forced banks to withdraw their excess reserves from the central bank and spend it onother ways. More recently, especially among regional banks, the demand for investment overseas has been increasing. Because the deposits the banks collect are in yen, they are investing in Europe in euro or in the US in dollars, creating an exchange rate risk. The suggestion to banks is to keep some portion of deposits in foreign currencies (euro, dollar, among others) to minimize the exchange rate risk.

Figure 12: Ineffectiveness of Monetary Policy in Japan

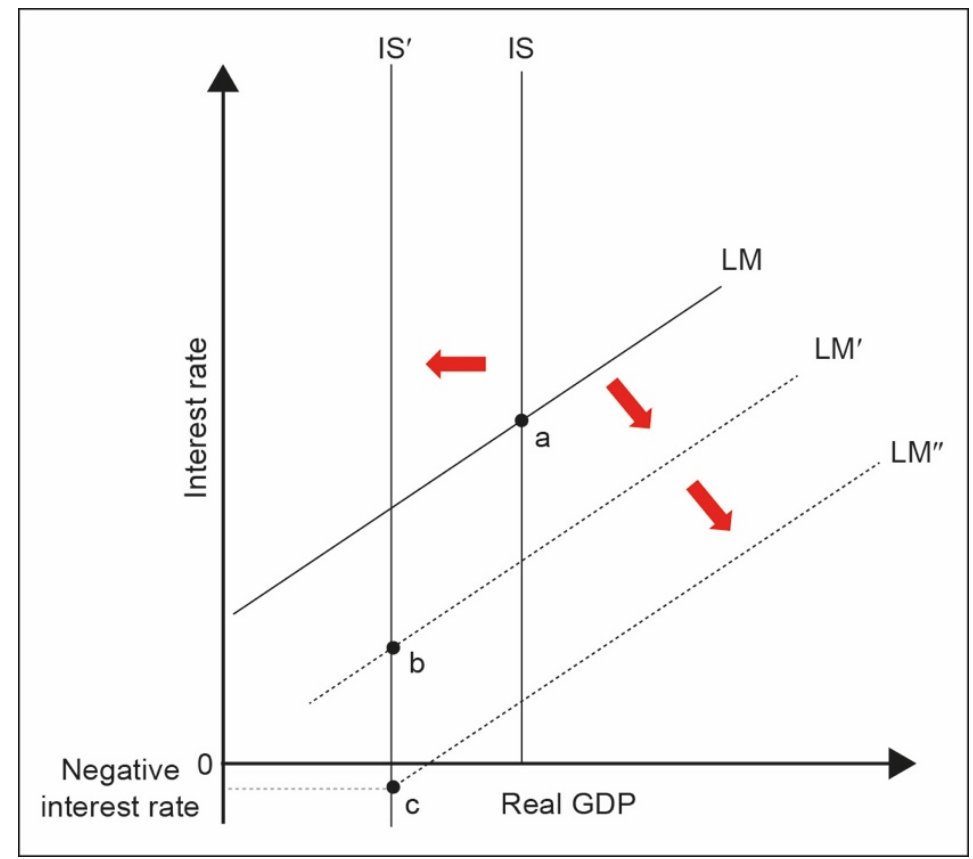

GDP = gross domestic product,LM = liquidity preference/money supply equilibrium . Source: Modified version of the table from Yoshino and Sakakibara (2002).

\section{SIMULATION RESULT}

Yoshino and Miyamoto (2016) examined how an aging population affects economic performance and effectiveness of macroeconomic policies by using a New Keynesian dynamic stochastic general equilibrium model. We demonstrate that the effects of monetary and fiscal policies are weakened when the working population becomes smaller. We also find that an increase in the proportion of workers boosts output, consumption, and investment in the long run. Thus, our analysis shows that the best 
policy for Japan would be to keep elderly people working by paying them the marginal product of labor. To do so, it is necessary to abolish the seniority wage rate and flatten the wage curve.

Figure 13 shows that the effect of monetary policy on the economy is weakened when the proportion of retirees is larger (i.e., the proportion of working population is smaller). Although the effect of an expansionary monetary policy (interest rate policy) on output may be similar between two economies, the effect of the policy on consumption in an economy with higher labor participation is much larger than that in an economy with fewer workers.

\section{Figure 13: Effects of Monetary and Fiscal Policy Shock on the Economy}

(a) Effects of an expansionary monetary policy (b) Effects of a positive government investment shock

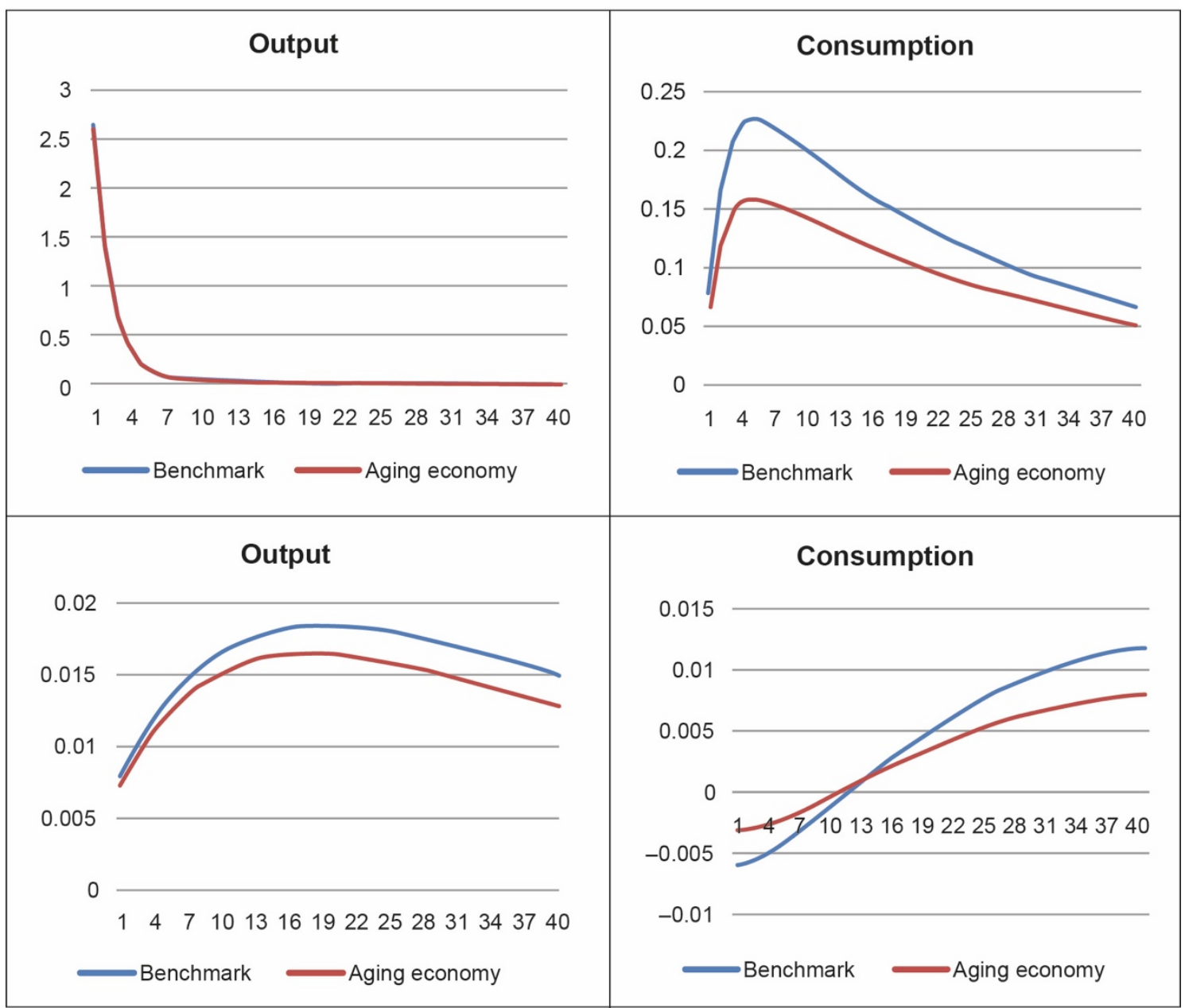

Note: For an expansionary monetary policy, responses to a decrease in the nominal interest rate are reported. For a positive fiscal policy shock, responses to an increase in government investment are reported. The blue lines labeled "benchmark" plot the impulse responses in the economy with large working population. The red lines labeled "aging economy" plot the impulse responses in the economy with lower working population. The horizontal axis represents quarters after the shock. The vertical axis represents percentage deviations from the steady-state value. Please see Yoshino and Miyamoto (2016) for more details.

Source: Yoshino and Miyamoto (2016). 
Figure 13 also shows that the effect of a positive government investment shock on output and consumption is larger in an economy with a higher proportion of workers in the total population.

These results mean that both monetary and fiscal policies become less effective in an aging economy.

We examine how an increase in the proportion of workers affects the economy. Figure 14 shows that an increase in labor participation increases output and aggregate consumption.

Figure 14: Effect of a Change in the Ratio of Workers to Population

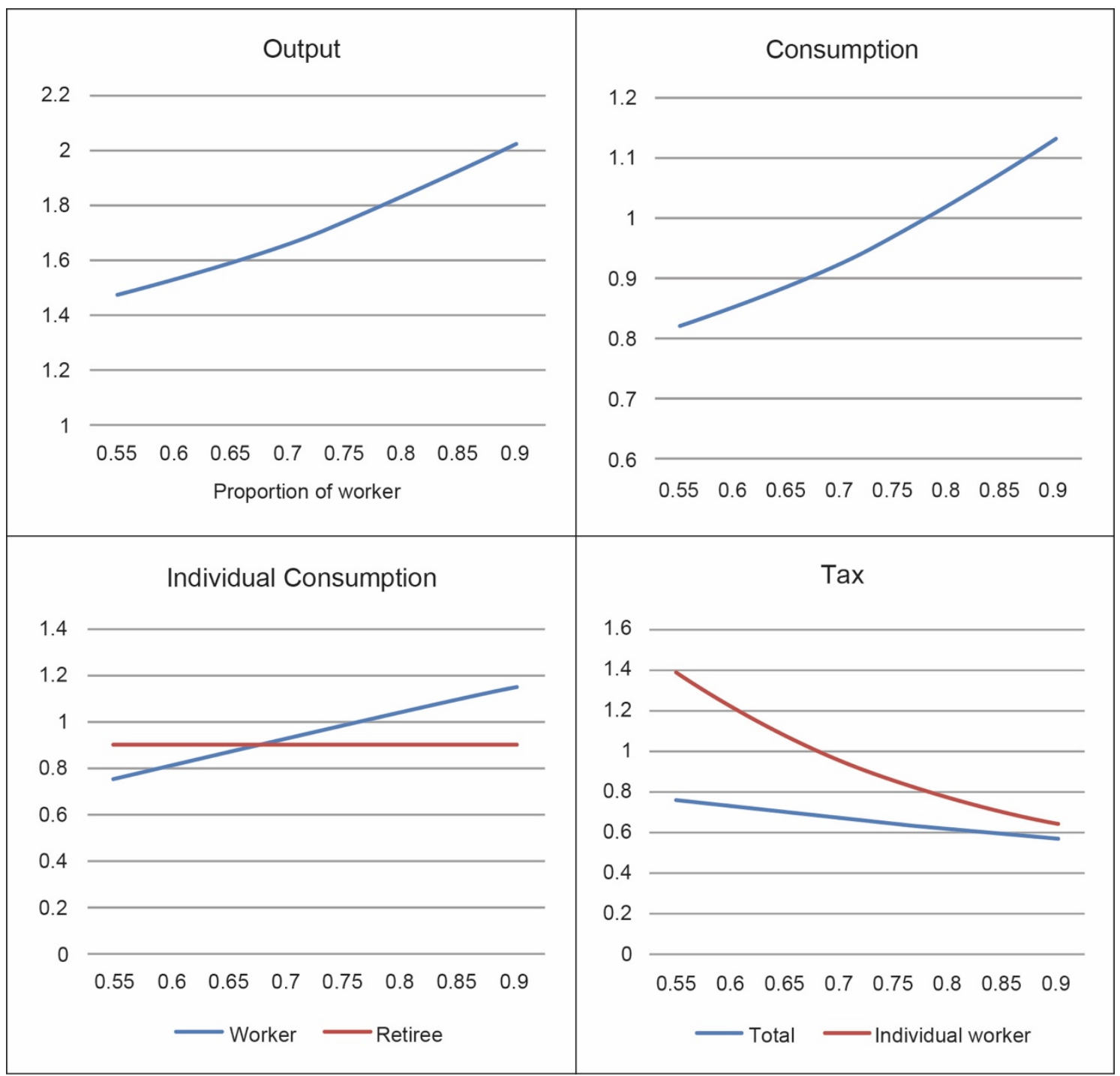

Source: Yoshino and Miyamoto (2016). 
This effect can be understood by looking at the responses of taxes paid by workers. In the economy, retirees receive pension benefits that are financed by imposing taxes on workers. Thus, pension benefits are transfers from tax payment by workers. Given the amount of pension benefits per retiree, an increase in the proportion of working population reduces the tax paid by each worker. This leads to an increase in consumption of workers and thus aggregate consumption. An increase in working population increases labor supply, which increases output.

Figure 14 implies that necessary policy to cope with an aging population is to keep old people working. Figures 13 and 14 imply that in an aging society, macroeconomic policies become less effective and it is better to increase the working population to boost the economy.

\section{CONCLUDING REMARKS}

Japan has reached the limits of conventional macroeconomic policies. To overcome deflation and achieve sustainable economic growth, the BOJ since 2013 has had an inflation target of $2 \%$ and implemented an aggressive monetary policy with a view to achieving this target as soon as possible.

On 29 January 2016, the BOJ took further steps and, to reach the $2 \%$ inflation target, introduced a negative interest rate policy. From February 2016, the short-term interest rate became negative, which later affected the medium-term and long-term interest rates, which also became negative. This policy flattened the yield curve of JGBs, which the BOJ did not expect to happen. Banks started to reduce the amount of government bonds they purchased because the interest rate for short-term government bonds became negative, and even for long-term government bonds up to 15 years the interest rate became negative.

Since 2013 , on the liability side of the BOJ's balance sheet, the monetary base has increased drastically by almost two and a half times as a result of the QQE policy. On the asset side of the BOJ's balance sheet, JGB holdings have accumulated and the BOJ holdings in 2016 are more than three times the amount of JGB stock compared to 2013. The total asset size of the BOJ in 2016 is almost two and a half times as large as in 2013.

Although the BOJ drastically raised the monetary base during the last 3 years, the $2 \%$ inflation target could not be achieved, except for short periods, mainly in 2014. One of the reasons behind the QQE policy's failureinachieving the $2 \%$ inflation target is the drop in oil prices.

Oil prices dropped from over $\$ 100$ per barrel in June 2014 to less than $\$ 30$ per barrel in February 2016. In 2015, Japan imported over $\$ 80$ billion of petroleum and petroleum products. Mineral fuel imports, including oil, made up $23 \%$ of total Japanese imports in 2015. This means the price of oil has a significant impact on shaping general price levels in Japan.

Although the price of oil is presently less than half what it was in 2014, the BOJ is still keeping the inflation target at $2 \%$. While the price of oil is declining because of the downward shift in aggregate supply, the equilibrium price level will be lower, meaning the government needs to adjust the inflation target below the $2 \%$ level. 
The BOJ introduced a negative interest rate policy, so that banks would withdraw excess reserves from the central bank and increase lending to the corporate sector and households, stimulating aggregate demand, raising prices, and accelerating economic growth. Following the BOJ's negative interest rate policy, banks did indeed withdraw excess reserves from the BOJ, but lending to the corporate sector did not increase. This is due to the vertical IS curve. Because of the aging population, a shrinking labor force, low participation of women in the workforce, a conservative banking system, less productive local governments, low levels of technological development, slow growth in small and medium-sized enterprises and startup businesses (Yoshino and Taghizadeh-Hesary 2014b, 2015c), the marginal productivity of capital is very low and the corporate sector's interest in investment has decreased, causing the IS curve to become vertical. This means that, although the BOJ is now strictly following the QQE policy, it could neither boost the economy nor raise the prices. In other words, the problems of the Japanese economy are structural and remedies could not be found in monetary policy. The Japanese government needs to focus more on the growth strategies of "Abenomics" (see Yoshino and Taghizadeh-Hesary 2015b) rather than on monetary policy. 


\section{REFERENCES}

Bank of Japan. 2016. Introduction of "Quantitative and Qualitative Monetary Easing with a Negative Interest Rate." 29 January.

Tokyo.https://www.boj.or.jp/en/announcements/release_2016/k160129a.pdf (accessed 30 December 2016).

Blanchard, O. J., and J. Gali.2007. The Macroeconomic Effects of Oil Shocks: Why Are the 2000s So Different from the 1970s? NBER Working Paper 13368.

Cambridge, MA: National Bureau of Economic Research.

Hamilton, J. D. 1996. This is What Happened to the Oil Price-Macroeconomy Relationship. Journal of Monetary Economics 38(2): 215-220.

International Energy Agency. 2016. Medium-term Oil Market Report 2016. Paris.

Japan External Trade Organization. 2016. Japanese Trade and Investment Statistics 2016. Tokyo.

Kilian, L. 2008. A Comparison of the Effects of Exogenous Oil Supply Shocks on Output and Inflation in the G7 Countries. Journal of the European Economic Association 6(1): 78-121. DOI: 10.1162/jeea.2008.6.1.78.

Lee, B. R., K. Lee, and R. A. Ratti. 2001. Monetary Policy, Oil Price Shocks, and the Japanese Economy. Japan and the World Economy 13(3): 321-349.

Ministry of Internal Affairs and Communication, Statistics Bureau. 2015. Statistical Handbook of Japan 2015. Tokyo.

Taghizadeh-Hesary F., and N. Yoshino. 2013. Which Side of the Economy Is Affected More by Oil Prices: Supply or Demand? USAEE Research Paper 13-139. Cleveland, $\mathrm{OH}$ : United States Association for Energy Economics.

- 2014. Monetary Policies and Oil Price Determination: An Empirical Analysis. OPEC Energy Review 38(1): 1-20. DOI: 10.1111/opec.1202.

2015. Macroeconomic Effects of Oil Price Fluctuations on Emerging and Developed Economies in a Model Incorporating Monetary Variables. Economics and Policy of Energy and the Environment 2: 51-75. DOI: 10.3280/EFE2015-002005.

Taghizadeh-Hesary, F., E. Rasolinezhad, and Y. Kobayashi. 2015b. Oil Price Fluctuations and Oil Consuming Sectors: An Empirical Analysis of Japan. ADBI Working Paper 539. Tokyo: Asian Development Bank Institute.

Taghizadeh-Hesary, F., N. Yoshino, G. Abdoli, and A. Farzinvash. 2013. An Estimation of the Impact of Oil Shocks on Crude Oil Exporting Economies and their Trade Partners. Frontiers of Economics in China 8(4): 571-591. DOI: 10.3868/s060002-013-0029-3.

Taghizadeh-Hesary, F., N. Yoshino, M. M. H. Abadi, and R. Farboudmanesh. 2015a. The Response of Macro Variables of Emerging and Developed Oil Importers to Oil Price Movements. Journal of the Asia Pacific Economy 21(1): 91-102. DOI: $10.1080 / 13547860.2015 .1057955$.

Yoshino, N., and E. Sakakibara. 2002. The Current State of the Japanese Economy and Remedies. Asian Economic Papers 1: 110-126.

Yoshino, N., and F. Taghizadeh-Hesary. 2014a. Monetary Policies and Oil Price Fluctuations Following the Subprime Mortgage Crisis. International Journal of 
Monetary Economics and Finance 7(3): 157-174. DOI: 10.1504/IJMEF.2014.066482.

2014b. Analytical Framework on Credit Risks for Financing SMEs in Asia. Asia-Pacific Development Journal 21(2): 1-21.

2015a. Effectiveness of the Easing of Monetary Policy in the Japanese Economy, Incorporating Energy Prices. Journal of Comparative Asian Development 14(2): 227-248. DOI: 10.1080/15339114.2015.1059059.

2015b. An Analysis of Challenges Faced by Japan's Economy and Abenomics. The Japanese Political Economy 40: 1-26. DOI: 10.1080/2329194X.2014.998591. 2015c. Analysis of Credit Risk for Small and Medium-Sized Enterprises: Evidence from Asia. Asian Development Review 32(2): 18-37. 2016a. Introductory Remarks: What's Behind the Recent Oil Price Drop? In Monetary Policy and the Oil Market, edited byN. Yoshino and F. Taghizadeh-Hesary. Tokyo: Springer. DOI: 10.1007/978-4-431-55797-5_1. 2016b. Causes and Remedies of the Japan's Long-lasting Recession: Lessons for China. China \& World Economy 24: 23-47. DOI: 10.1111/cwe.12149.

Yoshino, N., F. Taghizadeh-Hesary, A. Hassanzadeh, and A. D. Prasetyo. 2014. Response of Stock Markets to Monetary Policy: The Tehran Stock Market Perspective. Journal of Comparative Asian Development 13(3): 517-545. DOI: 10.1080/15339114.2014.985458. 